\title{
Coupling scenarios of urban growth and flood hazards along the Emilia-Romagna coast (Italy)
}

\author{
I. Sekovski ${ }^{1,2}$, C. Armaroli ${ }^{3}$, L. Calabrese ${ }^{4}$, F. Mancini ${ }^{5}$, F. Stecchi ${ }^{1}$, and L. Perini ${ }^{4}$ \\ ${ }^{1}$ Department of Biology, Geology and Environmental Science, University of Bologna, 48123 Ravenna, Italy \\ ${ }^{2}$ Department of Earth Sciences, CASEM, University of Cadiz, 11510 Puerto Real, Spain \\ ${ }^{3}$ Department of Physics and Earth Sciences, University of Ferrara, 44122 Ferrara, Italy \\ ${ }^{4}$ Geological Service of the Emilia-Romagna region, 40127 Bologna, Italy \\ ${ }^{5}$ DIEF, University of Modena and Reggio Emilia, 41125 Modena, Italy \\ Correspondence to: I. Sekovski (ivansekovski@gmail.com)
}

Received: 20 January 2015 - Published in Nat. Hazards Earth Syst. Sci. Discuss.: 1 April 2015

Revised: 24 September 2015 - Accepted: 25 September 2015 - Published: 14 October 2015

\begin{abstract}
The extent of coastline urbanization reduces their resilience to flooding, especially in low-lying areas. The study site is the coastline of the Emilia-Romagna region (Italy), historically affected by marine storms and floods. The main aim of this study is to investigate the vulnerability of this coastal area to marine flooding by considering the dynamics of the forcing component (total water level) and the dynamics of the receptor (urban areas). This was done by comparing the output of the three flooding scenarios (10, 100 and $>100$ year return periods) to the output of different scenarios of future urban growth up to 2050. Scenario-based marine flooding extents were derived by applying the CostDistance tool of ArcGIS ${ }^{\circledR}$ to a high-resolution digital terrain model. Three scenarios of urban growth (similar-to-historic, compact and sprawled) up to 2050 were estimated by applying the cellular automata-based SLEUTH model. The results show that if the urban growth progresses compactly, floodprone areas will largely increase with respect to similar-tohistoric and sprawled growth scenarios. Combining the two methodologies can be useful for identification of flood-prone areas that have a high potential for future urbanization, and is therefore crucial for coastal managers and planners.
\end{abstract}

\section{Introduction}

Today more than half of the world's population resides in cities (United Nations, 2014). Urban growth leads to changes in natural habitat, loss of open spaces and arable land, alter- ation of natural hydrological and sediment cycles, as well as an increased contribution to air and water pollution (UNFPA, 2007; Clarke, 2014). Worldwide urbanization processes are particularly intense in coastal zones, considering that over $40 \%$ of the global population live in areas within $100 \mathrm{~km}$ of the coastline (IOC/UNESCO, IMO, FAO and UNDP, 2011). This leads to an increased susceptibility of urban settlements to coastal hazards, such as flooding and erosion resulting from the impact of waves, tides, storm surges and sea-level rise (De Sherbinin et al., 2007; Hanson et al., 2011). Lowlying coastal areas are particularly vulnerable to such hazards, especially in delta regions, due to sediment compaction and related subsidence (Ericson et al., 2006; McGranahan et al., 2007). Apart from the visible impacts of temporary coastal inundation (e.g. damage to physical structures), some indirect effects can aggravate the problem, e.g. tourism decline, rise in insurance premiums for house-owners and other business disruptions (Lequeux and Ciavola, 2011; Meyer et al., 2013; Kreibich et al., 2014).

The main aim of this study is to investigate the vulnerability of coastal areas to marine flooding in a way that considers the dynamics of the forcing component (waves, tides and storm surge) and the dynamics of the receptor, i.e. urban areas. This was done by comparing the output of different coastal flooding scenarios to the output of diverse scenarios of urban growth in the coastal zone. This brings a more holistic viewpoint on issues of urbanization in flood-prone coastal areas, which can be beneficial for efficient coastal planning and management. 
The study was carried out in the coastal area of the EmiliaRomagna region, Italy. This area is known for intense urbanization along its low-lying setting, as well as for being susceptible to coastal flooding and the related beach erosion, mainly due to storm surges (Perini et al., 2011; Armaroli et al., 2012).

Urban growth scenarios were designed by employing the established cellular automata (CA)-based urban model named SLEUTH (Silva and Clarke, 2002). CA-based models have been recognized as particularly useful in simulating complex systems, such as cities, due to their ability to explicitly simulate spatial and time-related dynamics (Batty and Xie, 1997; Couclelis, 1997; White and Engelen, 2000; Irwin and Geoghegan, 2001; O'Sullivan and Torrens, 2000). Their affinity toward raster data makes them compatible with remote sensing and geographic information system (GIS) technology (Li and Yeh, 2000; Torrens, 2003). Among CA-based models, SLEUTH has recently gained popularity. There were several reasons for choosing SLEUTH in this work: it is available online for free and technical support is provided; it includes quite a robust routine for historical calibration; it has the ability to simulate different future growth scenarios; its output are GIF maps which are quite effective visualization tools; and, finally, it has been successfully applied in many recent studies on urban growth (Rafiee et al., 2009; Wu et al., 2009; Syphard et al., 2011; Al-shalabi et al., 2013; Dezhkam et al., 2013; Akın et al., 2014; Garcia and Loáiciga, 2014 among others). The only application of using SLEUTH to estimate future exposure to marine floods known to us is the one by Garcia and Loáiciga (2014). In their study the flood-damage quantification module was developed by merging flood maps with SLEUTH urbanization predictions in order to calculate the expected annual flood damage (EAFD) for given scenarios of sea-level rise. In general, the subject of growing population exposure to coastal flooding and sealevel rise has seemed to be more in focus lately (e.g. Jongman et al., 2012; Neumann et al., 2015; Stevens et al., 2015).

Hazard maps of the regional coastal area were issued at the end of 2013 to satisfy the requests of the EU Floods Directive. The 2007/60/EC (European Parliament and Council of the European Communities, 2007) Directive was implemented in Italy with the Decree 49/2010 and requests the member states to collect data, issue hazard maps and prepare disaster risk reduction plans, in order to reduce the negative consequences of river and marine flooding. It gives special attention to human lives and health, historical heritage, economic activities and infrastructure. To evaluate marine flooding hazards, the Geological Service of the Emilia-Romagna region followed a methodology that takes into account three total water level (TWL) scenarios (10, 100 and $>100$ year return periods) and high-resolution digital terrain models (DTMs) of the coast that were analysed with the Cost-Distance tool of ArcGIS ${ }^{\circledR}$ (Perini et al., 2012; Regione Emilia-Romagna, 2012a, b, 2013a; Armaroli et al., 2014). The Cost-Distance tool is a robust tool that is used for different purposes worldwide, ranging from measuring population exposure to pollution (Davies and Duncan, 2009), travel costs (among others, Bernd and Nielsen, 2007), habitat preservation under sea-level rise (Sims et al., 2013) and flooding extent due to sea-level rise (Xingong et al., 2014). It is defined as a tool that "calculates the least accumulative cost-distance for each cell to the nearest source over a cost surface" (i.e. computes the least "costly" path of each cell of a grid from a user-specified source or location; http://help.arcgis.com/en/arcgisdesktop/ 10.0/help/index.html\#//009z00000018000000.htm).

In summary, this study is aimed at reaching several objectives:

- to gain a deeper insight into historical urban growth of the coastal area of the Emilia-Romagna region;

- to discuss scenarios for future urban growth by adapting different development scenarios to the prerequisites of the SLEUTH urban model;

- to present a new methodology to estimate scenarios of the extent of coastal flooding and to produce hazard maps according to the EU Floods Directive;

- to overlay hazard maps onto future urbanization maps and discuss potential implementation of this approach in coastal planning and management.

\section{Study area}

The study focused on the coastal zone of the EmiliaRomagna region (Italy), located along the NW Adriatic Sea. Since there is no universal definition of a "coastal zone", the extent of the area was chosen arbitrarily, by considering the requisites for the SLEUTH model. A large urban centre in the area (the city of Ravenna) was included, because larger urban areas tend to influence the development of smaller ones in their surroundings (Antrop, 2004). The study area is included into a rectangle of approximately $76 \mathrm{~km}$ of length and $26 \mathrm{~km}$ of width, covering the area around the coastline that stretches from Sacca di Goro (Ferrara province) in the north to the city of Cesenatico (Forlì-Cesena province) in the south (Fig. 1).

In its northern part, the study area is a typical deltaic environment, characterized by reclaimed lowlands, wetlands and brackish lagoons. In ancient times, the natural river system of this area was subject to periodical floods that modified the hydrology and morphology of the Po River floodplain, causing damage to early settlements (Regione Emilia-Romagna, 2010a).

The southern part is extensively urbanized. Shoreward urbanization was driven by the tourism boom that started after World War II, being particularly intense during the 1960s. New settlements were managed mainly by real estate companies, which were buying agricultural land and selling it 


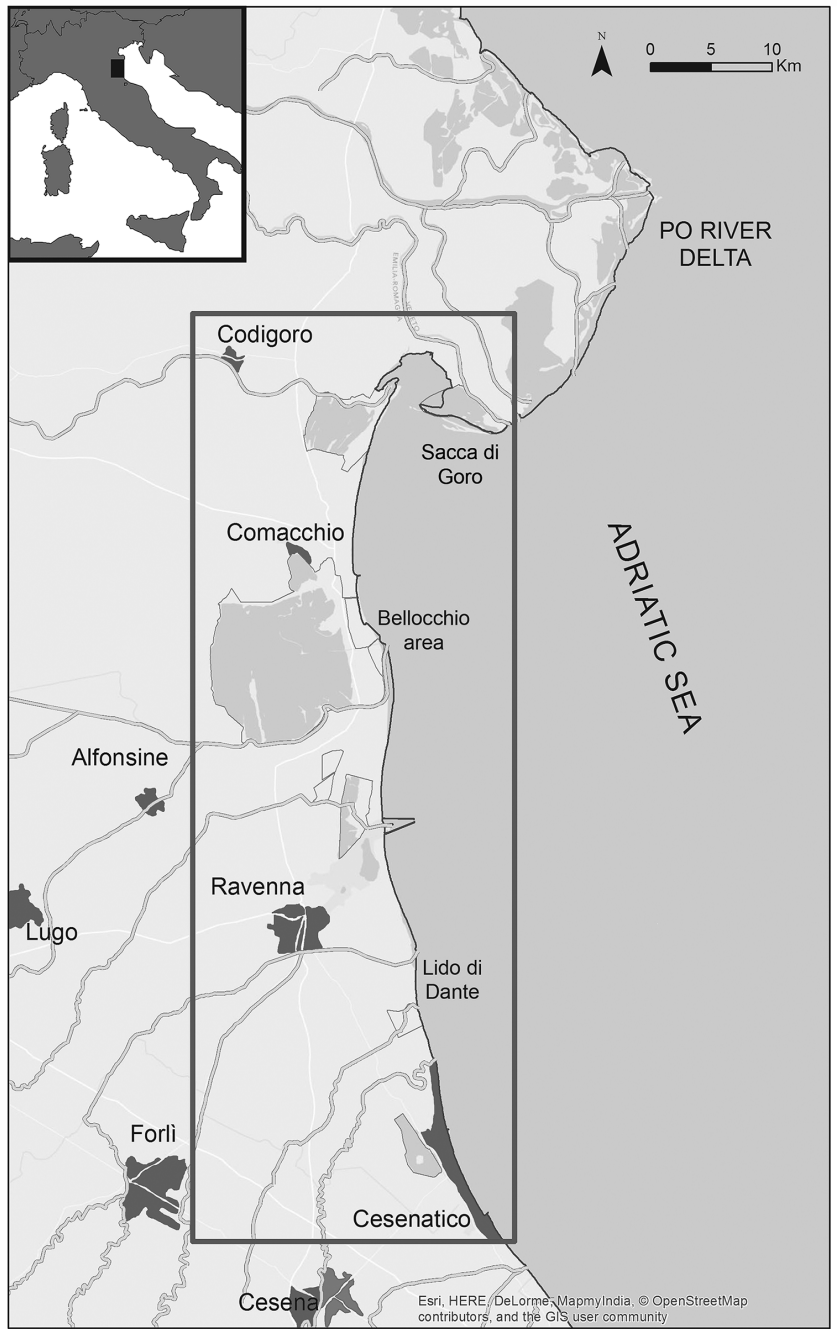

Figure 1. Study area: coastal zone of the Emilia-Romagna region (Italy).

for further development. This resulted in coastal land occupation by second homes and beach-bathing establishments known as "bagni" (Cencini, 1998). Beach-related tourism in the summer is a very important economic resource for the local community and for the whole region as well. The high degree of urbanization has meant that as of 2005, dunes are present along only $28 \%$ of the $130 \mathrm{~km}$ of coastline (Armaroli et al., 2012). Apart from beach-related tourism, land cover change was also driven by the development of oil and chemical industries, located particularly in the vicinity of the Ravenna harbour.

The Emilia-Romagna coast is characterized by very dissipative beaches composed of fine-to-medium sands and with low elevations above mean sea-level (mean height of the backshore is $1.45 \mathrm{~m}$ ) (Regione Emilia-Romagna, 2010a). The area is microtidal, with mean neap tidal range of $0.3-$ $0.4 \mathrm{~m}$ and mean spring tidal range of $0.8-0.9 \mathrm{~m}$ (Armaroli et al., 2012). The wave climate is low energetic, with $91 \%$ of significant wave height $\left(H_{\mathrm{s}}\right)$ below $1.25 \mathrm{~m}$. As for the storm surges, even the low return period events (e.g. a 1 in 10 year event) can lead to water level elevations of close to 1 m a.m.s.l. (Masina and Ciavola, 2011).

Along with reduced riverine sediment supply (Preciso et al., 2012), dune destruction, disruption of longshore sediment transport by harbours and piers and land subsidence (Teatini et al., 2005), marine storms are one of the major causes of coastal erosion. Intensive storms mainly originate from Bora (NE) and Scirocco (SE) winds (Ciavola et al., 2007). Most storms do not last more than $24 \mathrm{~h}$ and the maximum significant wave height is about $2.5 \mathrm{~m}$ (Armaroli et al., 2012). A historical review of coastal storms for the 19462010 period is discussed in detail in Perini et al. (2011).

Because of the high susceptibility of the coastal areas to marine ingression and coastal erosion, different coastal protection structures were built along the shoreline starting from the late 1970s. Approximately $57 \%$ of the coast is currently protected by artificial structures, such as submerged barriers and emerged breakwaters, groynes, etc. (Armaroli et al., 2009). These structures are able to protect the coast but can also generate erosion and interrupt longshore sediment transport. Along with other types of permanent embankments and protections, artificial "winter dunes" are a source of temporary protection that are built at the end of the summer season to avoid coastal flooding and damage (Harley and Ciavola, 2013).

Because of structural interventions, as well as beach nourishment practice, the coast is in a steady state at the present, with mean erosion and accretion rates between -1 and $+1 \mathrm{~m} \mathrm{yr}^{-1}$ (Armaroli et al., 2012). However, there are hotspots of erosion that show significant recession rates of up to $-15 \mathrm{~m} \mathrm{yr}^{-1}$, such as the Bellocchio area (Sekovski et al., 2014).

\section{Methods}

The workflow of this study consists of: (i) preparation of the input layers for the SLEUTH model; (ii) calibration of the SLEUTH model; (iii) prediction of urban growth of the Emilia-Romagna coastal area up to 2050, considering different development scenarios; (iv) development of different coastal flooding hazard maps; and (v) integration of urban growth predictions with flood hazard maps.

\subsection{SLEUTH model}

SLEUTH is a C-language source code that runs under UNIX or UNIX-based operating systems, publicly available by USGS (United States Geological Survey) and UCSB (University of California Santa Barbara) on the Project Gigalopolis website (http://www.ncgia.ucsb.edu/projects/gig/). Its acronym is derived from the data input requirements: 
Slope, Land use, Exclusion, Urbanization, Transportation and Hillshade.

SLEUTH can be described as a self-modifying, probabilistic and scale-independent CA model with Boolean logic, since each cell can be categorized only as urbanized or non-urbanized (Silva and Clarke, 2002; Gazulis and Clarke, 2006). Whether or not a cell is urbanized is defined via four transition rules of urban growth: spontaneity, diffusion, edge and road-influence. These rules are controlled by five coefficients, with values ranging from 0 to 100: dispersion (DI), breed (BR), spread (SP), road gravity (RG) and slope resistance (SR) (Clarke and Gaydos, 1998). All growth coefficients highly correlate to each other and their interaction exerts certain types of growth (Table 1). In addition, there is a self-modification process, which is one of SLEUTH's major characteristics. Without this feature, the growth would appear either as linear or exponential, which is not realistic (Silva and Clarke, 2002).

The simulation of historic urban growth and the forecast of future growth are performed through the calibration phase and the prediction phase. Detailed functioning of the SLEUTH model can be found in Candau (2002), Silva and Clarke (2002) and Jantz et al. (2003), among others.

\subsubsection{Input data preparation}

Input layers for SLEUTH were prepared in ArcGIS ${ }^{\circledR} 10.1$ software. Urban layers were digitized for the reference years 1978, 1990, 2000 and 2011 from topographic maps, satellite images and orthophotos. When digitizing urban layers, only the settlements set as urban areas by the Italian National Institute for Statistics (ISTAT, Istituto Nazionale di Statistica) were taken into account. Examples of urban growth for part of the study area is shown in Fig. 2.

Transportation layers were digitized for the years 1978 and 2011. Both layers considered roads ranked as provincial and national, as well as highways.

The hillshade and slope layers were created from a $10 \times 10 \mathrm{~m}$ digital terrain model (DTM), which was used to extract slopes given in percentage values, after resampling at $20 \mathrm{~m}$ resolution by using the nearest neighbour method.

Two different exclusion layers were used, following the recommendations of Onsted and Clarke (2012) and Akın et al. (2014): the historic exclusion layer utilized in the calibration phase, and the present exclusion layer utilized in the prediction phase. Both layers have joint exclusion areas which remained unchanged, such as the sea and inland water bodies. The present exclusion layer contains additional zones where construction is prohibited, such as:

- zones A, B and C based on Article 25 of "Regional law on formation and management of protected natural areas" (legge regionale 17 February 2005, no. 6);

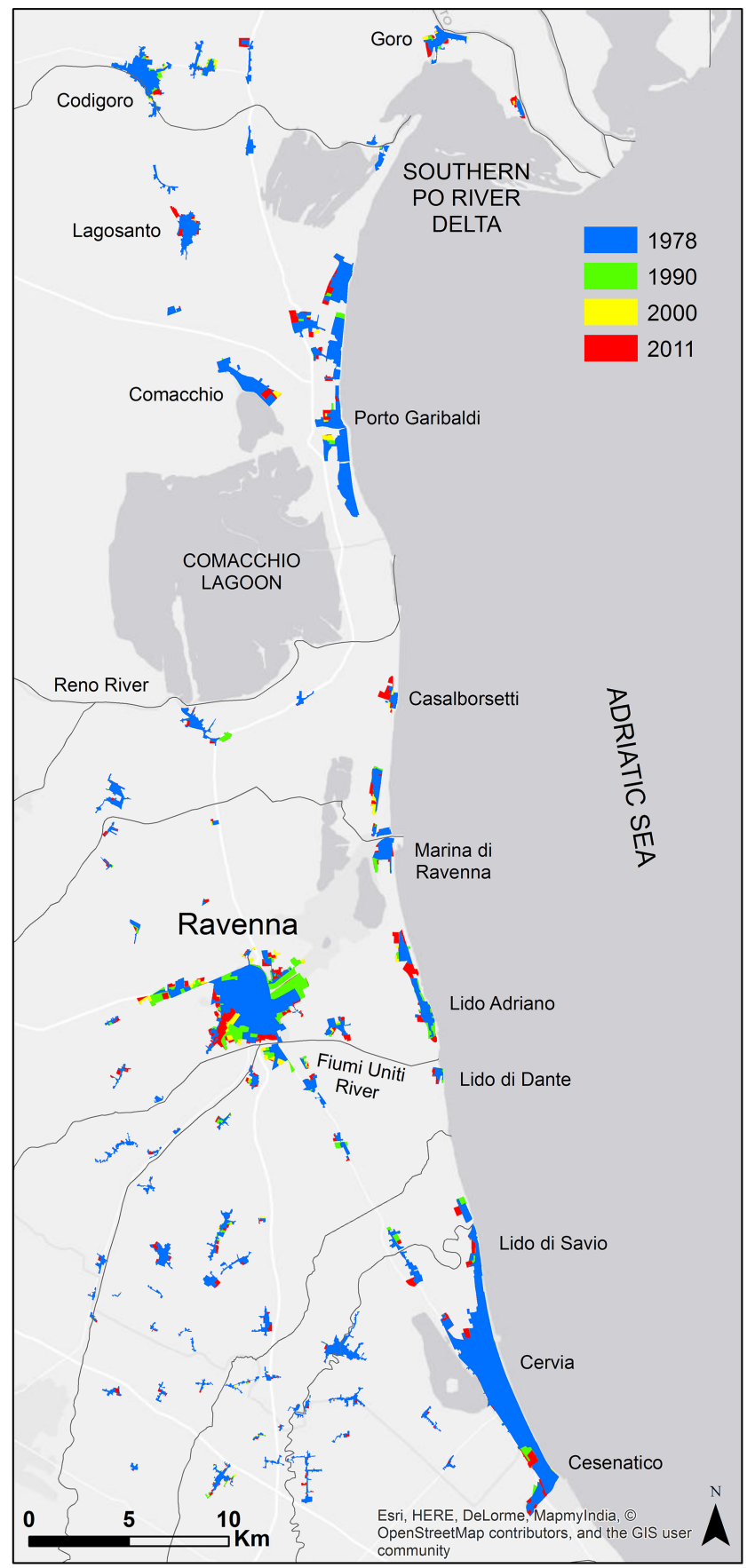

Figure 2. Urban development within the study area in the reference period.

- national reserves within the boundaries of the Regional Park of the Po Delta (called RNS or Riserve Naturali dello Stato);

- portions of national reserves outside these boundaries (e.g. Pineta di Ravenna); 
Table 1. Summary of growth types and controlling coefficients in SLEUTH (modified from Jantz et al., 2003 and Akın et al., 2014).

\begin{tabular}{llll}
\hline Growth cycle order & Growth type & Controlling coefficients & Description \\
\hline 1 & Spontaneous & Dispersion (DI) & Cells for new growth are randomly selected \\
2 & New spreading centre (diffusive) & Breed (BR) & Expansion from cells urbanized in spontaneous growth \\
3 & Edge (organic) & Spread (SP) & Expansion from existing urban centres \\
4 & Road-influenced & Road gravity (RG) + DI, BR & Growth along the transportation network \\
Throughout & Slope resistance & Slope resistance (SR) & Effects of slope in reducing the urbanization probability \\
Throughout & Excluded & User-defined & Areas excluded from or resistant to development \\
\hline
\end{tabular}

- sites of community importance (SIC or Siti di Importanza Communitaria) related to the Natura 2000 network of the EU Habitats Directive (92/43/EEC);

- zones of special protection (ZPS or Zone di Protezione Speciale) related to the EU Birds Directive (79/403/EEC);.

- archaeological sites classified as A, B1 and B2 after article 3.21.A of the Provincial Territorial Coordination Plan (PTCP) of the Ravenna province;

- $150 \mathrm{~m}$ buffer zones around river banks and $300 \mathrm{~m}$ landward buffer zones around shorelines according to the national law no. $431(08 / 08 / 1985$, the so-called Legge Galasso).

It is important to highlight that it was decided not to include the land not designated for urban development by official urban construction regulations (RUE or Regolamento Urbanistico Edilizio) in the Exclusion layer, since they belong to local planning which is more likely to be changed. Since the scenarios in this work are up to 2050 , only the areas protected at a higher regional, national and international level are considered excluded from urbanization.

Since the main focus of employing SLEUTH was urban change, land use, as an optional layer, was not used in this study.

Details on all input layers for SLEUTH are summarized in Table 2.

All input layers were then converted into $20 \mathrm{~m}$ resolution raster grids of 1323 columns by 3816 rows using SAGA software and saved as greyscale GIF images, as required by the SLEUTH model.

\subsubsection{Model calibration}

The main goal of the calibration phase is to determine the values of growth coefficients that simulate urban growth for certain historic time periods. SLEUTH calibration is carried out through a "Brute force" method which consists of three phases: coarse, fine and final (Goldstein, 2004). Growth is simulated multiple times by using the Monte Carlo method, an iterative procedure used for the computation of different spatial statistics (Syphard et al., 2005).

In the coarse-calibration phase, the widest range (1-100) of coefficient values is used, increased by 25 at a time. The range of coefficients values used in subsequent calibration phases (fine and final) is narrowed based on coefficient values that best replicate the historical growth in the previous phase. It is important to outline that the coefficient values resulting from the final calibration are usually not considered the best forecast of the historic growth. Apart from these three "classic" calibration phases, an additional phase named "derive" was computed. This phase, recommended by the Gigalopolis Project website, serves to avoid interference of self-modification constraints by obtaining the most robust coefficient values (more in Rafiee et al., 2009 and Ak1n et al., 2014). The resolution of the input images was kept the same throughout the calibration process. Indeed, it is common practice to lower the resolution to reduce computation intensiveness (Dietzel and Clarke, 2004), but Jantz and Goetz (2005) observed that changing the resolution of input layers may lead to inaccurate representation of growth.

In order to derive the coefficient range of each successive step of calibration, the goodness-of-fit metric called Optimal SLEUTH Metric (OSM) was used. It is a combination of compare, population, edges, clusters, slope, $X$-mean, and $Y$ mean metrics, which are considered to derive the most robust results (Dietzel and Clarke, 2007). More details on the OSM, as well on the metrics that it is composed of, can be found in Dietzel and Clarke (2007) and Onsted and Clarke (2012).

\subsubsection{Model prediction - urban growth scenarios}

There are three different approaches to the development of growth scenarios when applying SLEUTH: (i) changing the values of growth parameters obtained through the calibration phase (e.g. Leao et al., 2004; Rafiee et al., 2009; Dezhkam et al., 2013), (ii) assigning different protection levels to the exclusion layer (e.g. Oguz et al., 2007; Jantz et al., 2010), and (iii) manipulating the self-modification constraints (e.g. Yang and Lo, 2003). In this study, a combination of the first two approaches was used. Growth coefficients and exclusion levels were modified with the aim of establishing different scenarios of urban growth up to 2050. The prediction was executed by running 100 Monte Carlo iterations.

Three growth scenarios were designed in total. The first one was built using the same parameter values that resulted from the historic growth calibration, named "historic growth" scenario (HGS). The two other scenarios can be referred to as alternative urban growth scenarios: the "sprawled 
Table 2. Input data layers for SLEUTH.

\begin{tabular}{|c|c|c|c|}
\hline Input layer & Year & Source & Scale and spatial resolution \\
\hline \multirow[t]{4}{*}{ Urban } & 1978 & Topographic map Regione Emilia-Romagna & $1: 5000$ \\
\hline & 1990 & $\begin{array}{l}\text { LANDSAT satellite image provided by USGS (United States Geological } \\
\text { Service) through the GloVis (Global Visualization viewer) service } \\
\text { (http://glovis.usgs.gov) }\end{array}$ & $30 \times 30 \mathrm{~m}$ \\
\hline & 2000 & Orthophotos of the Istituto Geografico Militare (IGM) flight & $1: 29000,0.65 \mathrm{~m}$ \\
\hline & 2011 & $\begin{array}{l}\text { World Imagery base map feature (ArcGIS }{ }^{\circledR} 10.1 \text { ) based on high-resolution } \\
\text { imageries of western Europe provided by Digital Globe }{ }^{\circledR}\end{array}$ & $0.3 \mathrm{~m}$ \\
\hline \multirow[t]{2}{*}{ Transportation } & 1978 & Topographic map, Regione Emilia-Romagna & $1: 5000$ \\
\hline & 2011 & Italian National Geoportal (www.pcn.minambiente.it) & vector files \\
\hline Slope & 1979 & Digital terrain model (DTM) Regione Emilia-Romagna & $10 \times 10 \mathrm{~m}$ \\
\hline Hillshade & 1979 & Digital terrain model (DTM) Regione Emilia-Romagna & $10 \times 10 \mathrm{~m}$ \\
\hline \multirow[t]{2}{*}{ Exclusion } & $1980 \mathrm{~s}$ & Regional Po Delta Park & vector files \\
\hline & 2011 & $\begin{array}{l}\text { Emilia Romagna regional Geoportal } \\
\text { (http://geoportale.regione.emilia-romagna.it/en) }\end{array}$ & vector files \\
\hline
\end{tabular}

growth" scenario (SGS) and the "compact growth" scenario (CGS). Similar urban growth scenarios based on sprawled vs. compact types of growth were designed by Leao et al. (2004) and Solecki and Oliveri (2004).

In the SGS, new suburban and peri-urban centres are likely to emerge, mainly in existing agricultural and forested areas. The infilling, e.g. the growth inside and on the edges of existing urban areas, is expected to be minimal. In SLEUTH the dispersive growth is mainly controlled by DI and BR coefficients, therefore the rationale was to increase their values. Since the SGS considers low density development, sprawled growth could lead to greater travel distances which in turn can result in growth along the road networks. Therefore, the $R G$ coefficient was increased. Spatial planning is more aimed at how to satisfy the demand for new urban areas and thus, flexibility in current exclusion levels is expected. Exclusion layers were arbitrarily set to 80 , according to a detailed analysis of land cover evolution through time. It means that there is an $80 \%$ probability that the exclusion level will remain as such, without any urban development in the areas where urban development is allowed under certain conditions. In the study zone, these areas are SIC and ZPS sites, archaeological sites of B2 level and the buffer zones covered under "Legge Galasso" (see Sect. 3.1.1). The same value was used for the HGS.

In the CGS, compact-like growth of existing urban areas is much more likely to occur than the emergence of new spreading centres. In this case, the DI and BR values were lowered, while SP was increased since this coefficient reflects infilling growth. A more compact form of urban areas reduces the travel distances and, therefore, the RG values were lowered. Since sprawled growth is minimal, less demand for urbanization is expected outside the surroundings of already urbanized areas. Therefore, it would be less rational to allow construction in the areas that are currently protected. For that reason, the maximum exclusion levels were assigned to all polygons within the Exclusion layer (100).

It is important to note that prior to establishing the exact coefficient values for different scenarios, a sensitivity analysis was performed in order to examine how each single coefficient affects urban growth in this case. This was done by running the prediction by alternatively assigning a high value (80) to each coefficient while keeping the others as low as possible (1) (similar to Caglioni et al., 2006). The results indicated that the SP coefficient had by far the highest impact on urban growth (increase in urban cover by $11.25 \%$ ), while the DI, BR and RG coefficients resulted in a much lower increase in urban cover $(0.35,0.14$ and $0.11 \%$, respectively).

\subsection{Hazard maps}

The methodology adopted to produce flood hazard maps of the regional coastline was designed taking into account the impacts of historical storms that affected the regional coastline (i.e. the extension of flooded areas measured after important historical events and the characteristics of the events, such as wave and water levels, water depths of flooding, when available; Perini et al., 2015). The procedure used is based on two steps: (i) selection of the input forcing data and computation of total water levels for three return periods (Perini et al., 2012; Regione Emilia-Romagna, 2012a, b); (ii) compilation of a model into ArcGIS ${ }^{\circledR}$ ModelBuilder to elaborate input data and produce hazard maps (Regione Emilia-Romagna, 2012a, b, 2013a, b).

The forcing components were selected in order to compute maximum water levels of three scenarios that were considered significant by regional authorities and also complied with the requests of the EU Floods Directive. The total water 
level (TWL) for the 1 in 10, 1 in 100 and more than 1 in 100 year return period event (Table 3) was computed as the sum of three components that were extracted from the literature: surge levels (Masina and Ciavola, 2011), wave set up elevations (Decouttere et al., 1998) and finally, the astronomic high spring tide level $(0.40 \mathrm{~m}$ above reference level that is the MSL in Genoa; Idroser, 1996). The more than 1 in 100 year return period TWL was extracted from the first coastal plan issued by the local government of the Emilia-Romagna region (Idroser, 1982) in which an analysis of extreme events was presented. Run-up levels, land subsidence and scenarios of sea-level rise were not included into the computation, as it was decided to design a simplified and faster methodology, calibrated on historical information and on the large coastal database of the local regional government. For the same reasons, sources of temporary protection, such as the so-called "winter dunes" (Harley and Ciavola, 2013), were not included in the analysis, even if they proved to be effective in protecting the rear part of the beach from storm impacts (Harley and Ciavola, 2013).

Once TWLs were available, they were compared to highresolution DTMs, following the so-called "bathtub method" (Poulter and Halpin, 2008), but the results were unrealistic, because the low-lying nature of the coastline, especially its northern part, led to an overestimation of the flooding extension. In order to obtain reliable information on the extent of flooded areas, an attenuation artifice was introduced. The artifice consists of projecting the water surface landward following a sloping plane. The projection angle was chosen through the analysis of inundation maps compiled after major storms (Perini et al., 2011), considering the less conservative conditions (i.e. the angle computed for storms that caused the most landward inundation). The obtained value was cotangent $=0.002$, that is the angle between the water surface at the shoreline (with an elevation corresponding to the maximum water level measured during the storm) and the most landward location of flooding. Resulting hazard maps were more realistic in some areas if compared to historical storms (i.e. locations where it was possible to validate the results), while others still showed unrealistic results, especially those stretches of coast characterized by continuous alongshore human/morphologic elements (i.e. dunes, dikes, roads, artificial sand/earth embankments with an elevation higher than the computed TWL of each scenario) and low-lying areas in their lee. These low-elevation areas are classified as flood-prone but, according to the information included in the historical storm database (Perini et al., 2011), they are safe from inundation under forcing conditions similar to the designed scenarios, due to the protection given by the alongshore ridges that act as barriers able to stop the water flow landward. In order to address these problems, the Cost-Distance tool of ArcGIS ${ }^{\circledR}$ was applied and a new model was built into ArcGIS $^{\circledR}$ to further elaborate the data (Fig. 3). The tool was used to reclassify the high-resolution DTM (2008, resolution $2 \times 2 \mathrm{~m}$ ) in order to assign to each cell of the grid a value that

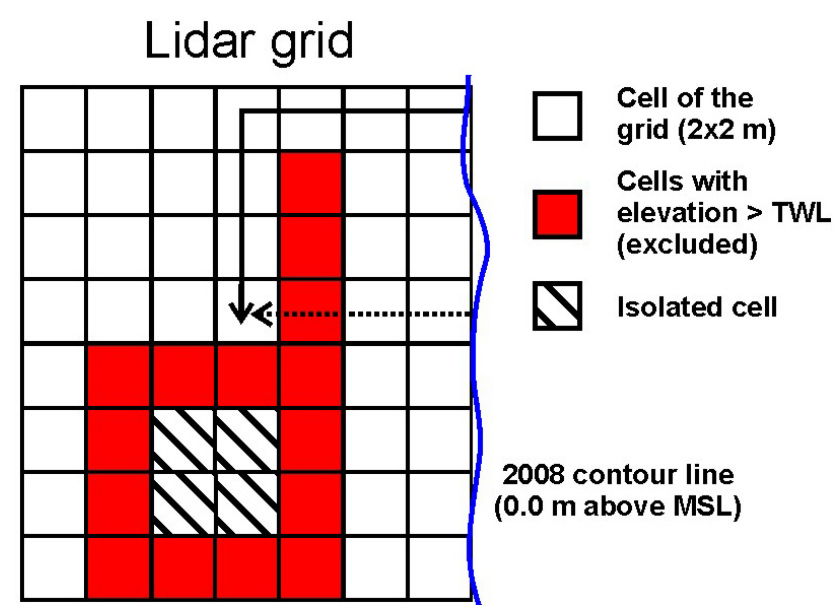

Figure 3. Schematic example of the method applied to produce hazard maps: red squares are excluded areas (elevation > TWL of each scenario, step 1); the squares with oblique black lines identify an isolated area (there are no paths that connect the shoreline to that area, i.e. the area is safe from inundation, step 2). Difference between the least path method and the Euclidean distance: the black arrow indicates the least path that connects the shoreline to the cell, calculated with the Cost-Distance tool (cumulative distance $=7$ cells, i.e. $14 \mathrm{~m}$ because one cell is $2 \times 2 \mathrm{~m}$ ); the dashed arrow indicates the Euclidean distance.

corresponds to its distance from the $0.0 \mathrm{~m}$ contour line (the "source") extracted from the 2008 lidar grid, not in terms of Euclidean distance, but in terms of least cumulative distance. The tool is in fact designed to calculate the least path that connects each cell of a grid to the origin (2008 contour line).

The model built into ArcGIS ${ }^{\circledR}$ follows the listed steps.

1. The high-resolution DTM is reclassified to exclude all human/morphological elements that have an elevation > TWL of each scenario.

2. The reclassified DTM is used together with the shoreline location (the "source") as input into the CostDistance tool. The output is a DTM where each cell is assigned a "distance" value that represents the least accumulative distance that the water has to cover from the shoreline to reach a specific location. Pixels excluded in the first step are not taken into account in the computation. The procedure allows the identification of isolated areas that are not reachable by the water (i.e. there are no paths that connect the "source" to those areas) and, on the other hand, identifies specific locations that can act as passages for the landward movement of the water.

3. The attenuation angle (cotangent $=0.002$ ) is finally used to convert the distance values of each grid cell into heights that represent the water depth that is needed to cause inundation: the longer the path is, the higher the computed height (i.e. water depth) is, thus increasingly higher water levels are needed to inundate areas that are 
Table 3. Total water level values of each scenario. See comments on RP > 100 total water level computation in the text.

\begin{tabular}{llrrrr}
\hline Scenario & $\begin{array}{l}\text { Return period } \\
\text { - RP (years) }\end{array}$ & $\begin{array}{r}\text { Storm surge value } \\
(\mathrm{m} \text { a.m.s.l.) }\end{array}$ & $\begin{array}{r}\text { Mean astronomical spring } \\
\text { high tide (m a.m.s.l.) }\end{array}$ & $\begin{array}{r}\text { Mean wave set-up value } \\
(\mathrm{m} \text { a.m.s.l.) }\end{array}$ & $\begin{array}{r}\text { Total water level } \\
(\mathrm{m} \text { a.m.s.l.) }\end{array}$ \\
\hline Frequent & $\mathrm{RP}=10$ & 0.79 & 0.40 & 0.30 & 1.49 \\
Low frequent & $\mathrm{RP}=100$ & 1.02 & 0.40 & 0.39 & 1.81 \\
Rare & $\mathrm{RP}>100$ & - & - & - & 2.5 \\
\hline
\end{tabular}

far from the shoreline or that are connected to the shoreline by longer paths.

4. The DTM is reclassified again based on the results of the tool: if the height of a cell, obtained through the previous step, is $<=$ TWL of each scenario then that cell is flood-prone, otherwise the cell is safe from inundation.

5. The location and extension of flood-prone areas are translated into polygon features that represent the hazard maps (one polygon feature for each scenario).

The inundated areas were classified according to the selected return periods (RPs) as P1: "rare" (> 100 year RP); P2: "not frequent" (100 year RP) and P3:"frequent" (10 year RP) degree of hazard. The hazard maps were compared to in situ surveys of the extension of water intrusion landward, carried out after major storms.

The model set-up (i.e. model construction) requires few minutes. The model run takes almost $3 \mathrm{~h}$ considering also $30 \mathrm{~min}$ for input data preparation and independently from the modelled scenario. The model is run along $20-25 \mathrm{~km}$ of coastline at a time (five sectors). Once the methodology is set, the model itself is quite rapid. The time-consuming part of the presented procedure is the collection of historical storm information and the trial-and-error procedure.

Finally, each polygon set representing three TWL scenarios was overlaid with SLEUTH output maps representing three urban growth scenarios. This resulted in nine integrated scenarios showing areas where flood extent intersected the future urban growth. It enabled us to visualize vulnerable areas and further standard analyses were performed to calculate, for instance, the extent of urban growth that falls under flooded areas. The additional urban cover that falls under each of three TWL scenarios in 2050 was expressed in both $\mathrm{m}^{2}$ and $\%$ with respect to 2011 urban cover.

Since SLEUTH output GIFs have the inherent property to express urbanization probability, we considered only the pixels that show $80 \%$ or more of urban growth probability as reliable to take the above calculations into account.

The complete methodology overview is schematized in Fig. 4.

\section{Results}

\subsection{SLEUTH model}

\subsubsection{Model calibration}

The resulting values of the calibration parameters, concerning all calibration phases, are visualized in Table 4. The coefficient range for the successive steps of calibration was selected by examining the top three rankings of the OSM values, as indicated on the official Project Gigalopolis website. The highest OSM value increased with each calibration step (from 0.38 in coarse to 0.397 in final phase), meaning that the resemblance between modelled and observed data improved as calibration progressed.

Low final values of the DI (1) and the BR (1) coefficients imply that there was very little sprawled growth in the coastal area in a given historic period. The higher value of the SP coefficient (30) indicates that growth occurred in a more compact manner around the existing urban areas. The high value (52) of the RG coefficient means that the transportation network played an important role in the urbanization evolution. The low value of the SR coefficient (1) was somewhat expected, since the study area is characterized by low slope variations and, therefore, slope is not a limiting factor for growth.

\subsubsection{Model prediction}

Table 5 lists the values of each coefficient used to design the alternative SGS and CGS, and the values used to design the HGS (i.e. resulting from the calibration phase). The alternative scenarios were designed as follows.

1. DI, BR and RG coefficient values were increased by 25 in the SGS, while DI and BR remained at minimal value, with RG decreased by 25 , in the CGS.

2. The SP coefficient was decreased and increased by 10 in SGS and CGS, respectively.

3. As the slope has proven not to be a limiting factor for urbanization, the SR was not modified.

It should be mentioned that since the sensitivity analysis showed that SP has the highest impact on to-urban conversion, changing it with the same values used for DI, BR and 
SLEUTH implementation

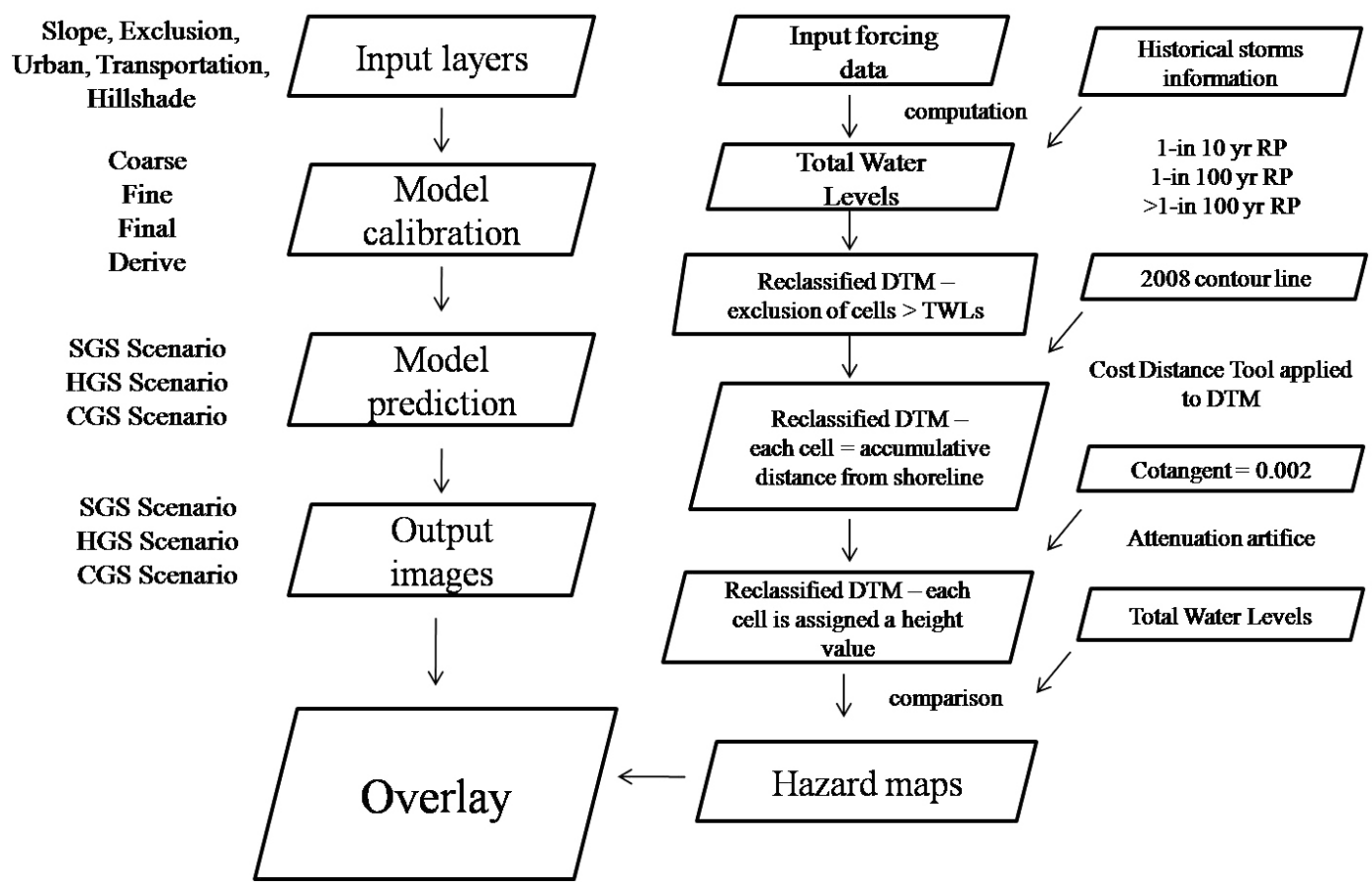

\section{Hazard maps}

Figure 4. Flow diagram showing the complete methodological procedure.

Table 4. SLEUTH calibration parameters for 1978-2011 historic urban growth of the Emilia-Romagna coastal area.

\begin{tabular}{lrrrrrrrrrr}
\hline & \multicolumn{2}{c}{$\begin{array}{c}\text { COARSE } \\
\text { Monte Carlo } \\
\text { iterations: } 4\end{array}$} & \multicolumn{2}{c}{$\begin{array}{c}\text { FINE } \\
\text { Monte Carlo } \\
\text { iterations: } 7\end{array}$} & $\begin{array}{c}\text { FINAL } \\
\text { Monte Carlo } \\
\text { iterations: } 9\end{array}$ & \multicolumn{2}{c}{$\begin{array}{c}\text { DERIVE } \\
\text { Monte Carlo }\end{array}$} \\
\cline { 2 - 13 } Growth coefficients & Range & Step & Range & Step & Range & Step & Final & Range & Step & Final \\
\hline DI & $1-100$ & 25 & $0-20$ & 5 & $0-5$ & 1 & 1 & $1-1$ & 1 & 1 \\
BR & $1-100$ & 25 & $0-20$ & 5 & $0-5$ & 1 & 1 & $1-1$ & 1 & 1 \\
SP & $1-100$ & 25 & $15-35$ & 5 & $20-30$ & 2 & 24 & $24-24$ & 1 & 30 \\
SR & $1-100$ & 25 & $0-75$ & 10 & $0-10$ & 2 & 10 & $10-10$ & 1 & 1 \\
RG & $1-100$ & 25 & $0-50$ & 10 & $10-50$ & 5 & 50 & $50-50$ & 1 & 52 \\
\hline
\end{tabular}

Table 5. Prediction coefficient values for different scenarios.

\begin{tabular}{lrrrrr}
\hline Scenario & \multicolumn{5}{c}{ Coefficient values } \\
\cline { 2 - 6 } & DI & BR & SP & SR & RG \\
\hline Historic growth scenario (HGS) & 1 & 1 & 30 & 1 & 52 \\
Sprawled growth scenario (SGS) & 25 & 25 & 20 & 1 & 77 \\
Compacted growth scenario (CGS) & 1 & 1 & 40 & 1 & 27 \\
\hline
\end{tabular}

RG (i.e. 25) could result in under- or overestimated growth levels (Perini et al., 2015).

Within the whole extent of the study area, the HGS predicts an increase of urbanization by $3.6 \%$ up to 2050 . The growth rate reaches a peak in the whole period between 2019 
1) lead to a consistent increase of urbanized areas. It seems that a more compact type of historic growth made a mark on the prediction phase. This type has proven to be a characteristic of the study area and this is also evident after the calibration phase. The resulting GIF maps of the SGS show that although some sparse urbanized areas appear, their probability of occurrence is less than $20 \%$. In order to provide an example at an appropriate spatial scale, Figure 5 depicts urban growth scenarios within a smaller geographical extent including the southern portion of Lido Adriano and the village of Lido di Dante. This area is among the coastal settlements that, at the present, undergo frequent flooding episodes (Perini et al., 2011).

\subsection{Coastal flood extent and overlay with SLEUTH's output maps}

The results of the SLEUTH model predictions were compared to the hazard maps issued by the local government of the Emilia-Romagna region (Table 6). If the current urban area extent (2011) is taken into account, the number of floodprone areas increases 3 times between $T 10$ and $T 100$ and the same between $T 100$ and $T>100$. The results show that if the urban growth of the coastal area follows the CGS, floodprone areas will largely increase with respect to the HGS. The extent of additional flood-prone areas according to CGS, for each flood scenario, is almost twice as large as the HGS.

\section{Discussion}

According to SLEUTH predictions, urban growth is not likely to change from compact to sprawled in the EmiliaRomagna coastal area in the future. If the urbanization continues to increase, it will probably take place around the existing urban areas in a more compact manner.

It is important to highlight that the compact historic growth, highly dependent on the proximity to road networks, is exclusively related to the studied historic period. Considering the fact that the biggest boom in urbanization took place in the 1950s, and especially in the 1960s (Cencini, 1998), it would be interesting to observe the output of a calibration phase in which the "seed year" starts before the mentioned period. However, quality data needed as input for SLEUTH were not available for the period earlier than 1978, so this remains a recommendation for further research. On the other hand, it seems that the availability of more recent data sets, with shorter time intervals between them, can result in a more accurate agreement between the simulated and observed urbanization (Candau, 2002; Chaudhuri and Clarke, 2014).

The limitation of urban models is that they often do not capture the driving forces behind urbanization (Herold et al., 2003; Jantz et al., 2003). The main drivers of urban growth are population increase and economic development (Rounsevell et al., 2006). The population of the Emilia-Romagna region is expected to increase by almost $13 \%$ up to 2030 (Regione Emilia-Romagna, 2010b) and, therefore, the demand for urbanization is likely to increase accordingly. The demand can be amplified by the economic growth, but economic growth rates are difficult to predict, especially for longer periods. Since the driver of coastal urbanization is highly related to second homes and tourism, it would be crucial to include the expected growth in population well-being and economic activities in this analysis. In addition, sectors such as tourism and trade greatly rely on economic trajectories that go beyond regional boundaries and are not taken into account in CA models (Torrens, 2003).

Some uncertainties arise when applying the SLEUTH model. One is the uncertainty of how much to increase/decrease the coefficient values in order to represent the scenarios as realistically as possible. A second uncertainty is the designation of exclusion levels. Exclusion levels have proven to have a crucial role in previous SLEUTH applications (Akın et al., 2014). It is common that excluded areas are weighted (Dietzel and Clarke, 2007; Akın et al., 2014), so that some areas can be only partially excluded. For this reason the value for the HGS and the SGS was set to $80 \%$. However, if the demand for urban land increased, the excluded areas could be considered suitable for urban development and hence the weighted exclusion values should be set lower.

When discussing the Cost-Distance tool for calculating scenario-dependant flood extents, there are some details that need to be considered. First of all, the analysis does not include formulas to calculate the run-up, which can be critical when estimating flooded areas (Armaroli et al., 2009). In addition, this methodology does not take into account the morphological evolution of beaches and dunes in front of urban settlements over a short period of time (e.g. related to storm impacts) and thus does not include dune/artificial embankment breaching and overwash/overtopping processes. Furthermore, it does not consider land subsidence that is a critical aspect in the study area. Land subsidence ultimately controls medium-term morphological resilience of dunes and back-barrier environments through complex feedback interactions between biotic and abiotic components (Taramelli et al., 2015). Finally, it offers information neither on flow velocity nor on soil permeability. Without these parameters, the calculations of flood polygon areas can easily be under- or overestimated. Nevertheless, the tool calculates the shortest path that the water covers to move landward, which can be considered a proxy of soil roughness and permeability. The longer the path, the less flood-prone the area, according to the applied methodology. Furthermore, the model excludes from the computation several zones that are not reachable by water; on the contrary, it detects the location of low-lying/open passages that favour the landward water movement. This information is particularly interesting for coastal managers as it can be translated into a list of vulnerable locations which are in need of special attention for risk reduction measures. 

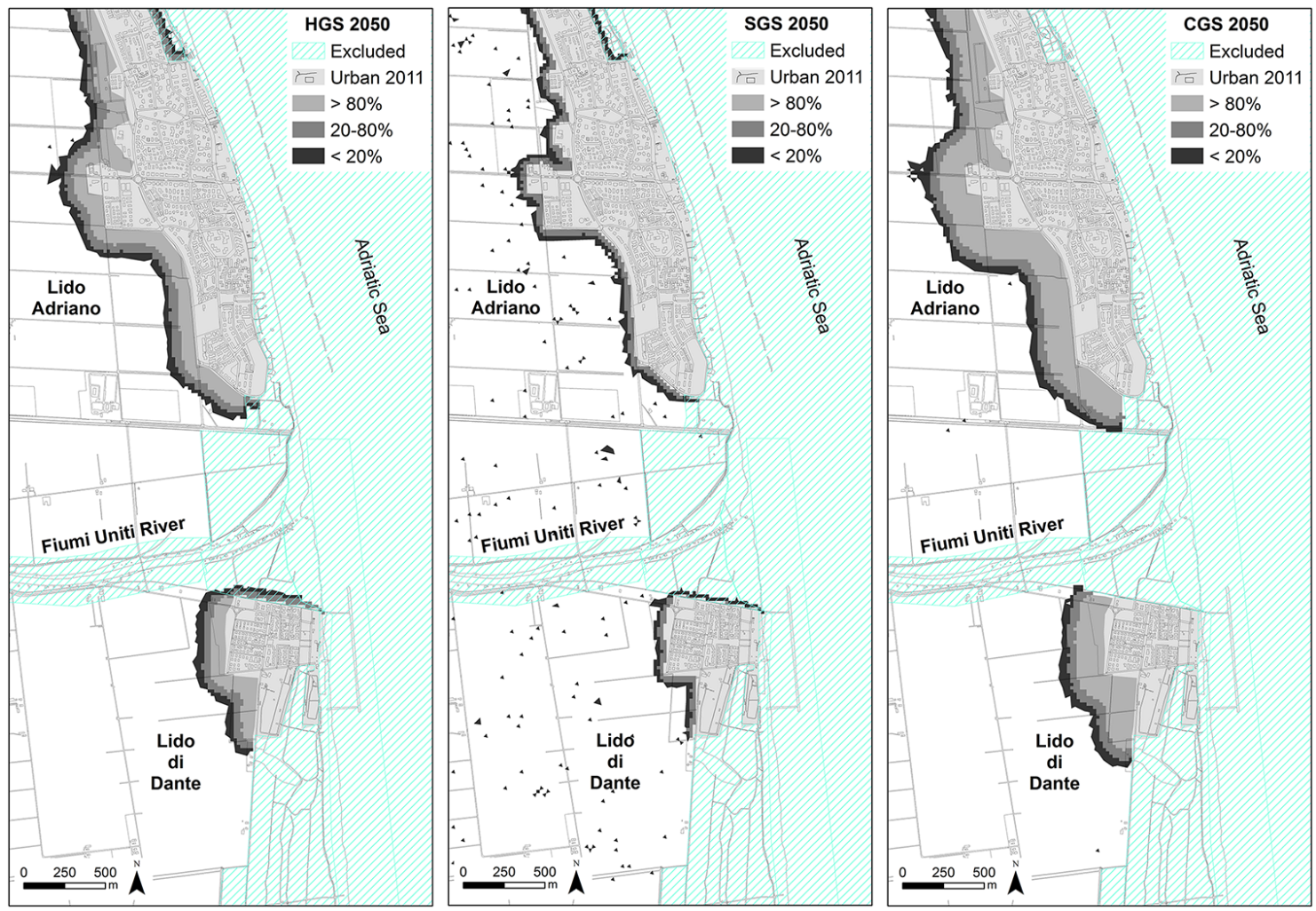

Figure 5. Difference between the HGS, the SGS and the CGS for the year 2050: example of Lido Adriano and Lido di Dante, Ravenna.

Table 6. Results of overlay of TWL scenarios with SLEUTH prediction scenarios.

\begin{tabular}{|c|c|c|c|c|c|c|c|c|}
\hline \multirow[t]{2}{*}{$\begin{array}{l}\text { Scenarios } \\
\text { - hazard maps }\end{array}$} & \multirow[t]{2}{*}{$\begin{array}{l}\text { Extent of coastal } \\
\text { flooding }\left(\mathrm{m}^{2}\right)\end{array}$} & \multirow[t]{2}{*}{$\begin{array}{r}\text { Extent of } 2011 \text { flood-prone } \\
\text { urban areas }\left(\mathrm{m}^{2}\right)\end{array}$} & \multicolumn{3}{|c|}{$\begin{array}{l}\text { Extent of additional } \\
\text { flood-prone } \\
\text { urban areas up } \\
\text { to } 2050\left(\mathrm{~m}^{2}\right)\end{array}$} & \multicolumn{3}{|c|}{$\begin{array}{l}\text { Extent of additional } \\
\text { flood-prone } \\
\text { urban areas up } \\
\text { to } 2050(\%)\end{array}$} \\
\hline & & & HGS & SGS & CGS & HGS & SGS & CGS \\
\hline$T 10$ & 14184867 & 1691330 & 151101 & 256. & 249,190 & 8.93 & 0.015 & 14.73 \\
\hline$T 100$ & 24740304 & 5210865 & 694121 & 5424 & 1154793 & 13.32 & 0.10 & 22.16 \\
\hline$T>100$ & 68847407 & 15466773 & 1953043 & 11,748 & 3467888 & 12.62 & 0.07 & 22.42 \\
\hline
\end{tabular}

Regarding the predicted urban growth in the study area, some remarkable insights were revealed. First of all, there is no space for further urban development in areas directly facing the coastline. The coastal stretch of the study area is either already urbanized or excluded from development. Therefore, a great majority of future urbanized areas that fall under flooding polygons are located in the hinterlands of existing coastal settlements. This is clear on the given example of Lido Adriano-Lido di Dante (Fig. 6a-f). This urbanized area was chosen for the demonstration of the results since a considerable portion of urban growth areas fall under different scenarios of future flood extent. Two opposite scenarios of urban growth (CGS and SGS) were chosen for the demonstration (HGS was left out for visualization purposes).
If the urban growth increases at the same pace as it has been increasing along the historic period used for calibration, the growth of urban areas will be quite limited (the HGS). The extension of urban areas that are flood-prone to highfrequency events ( $T 10)$ in current urban settlements (2011) is $12 \%$ of the total inundated area. Indeed, if the urbanization happens in a compact manner, which is most likely, the risk will increase accordingly, and the number of flood-prone zones will rise between 14 and $23 \%$ up to 2050, with respect to the extension of current flood-prone areas. 

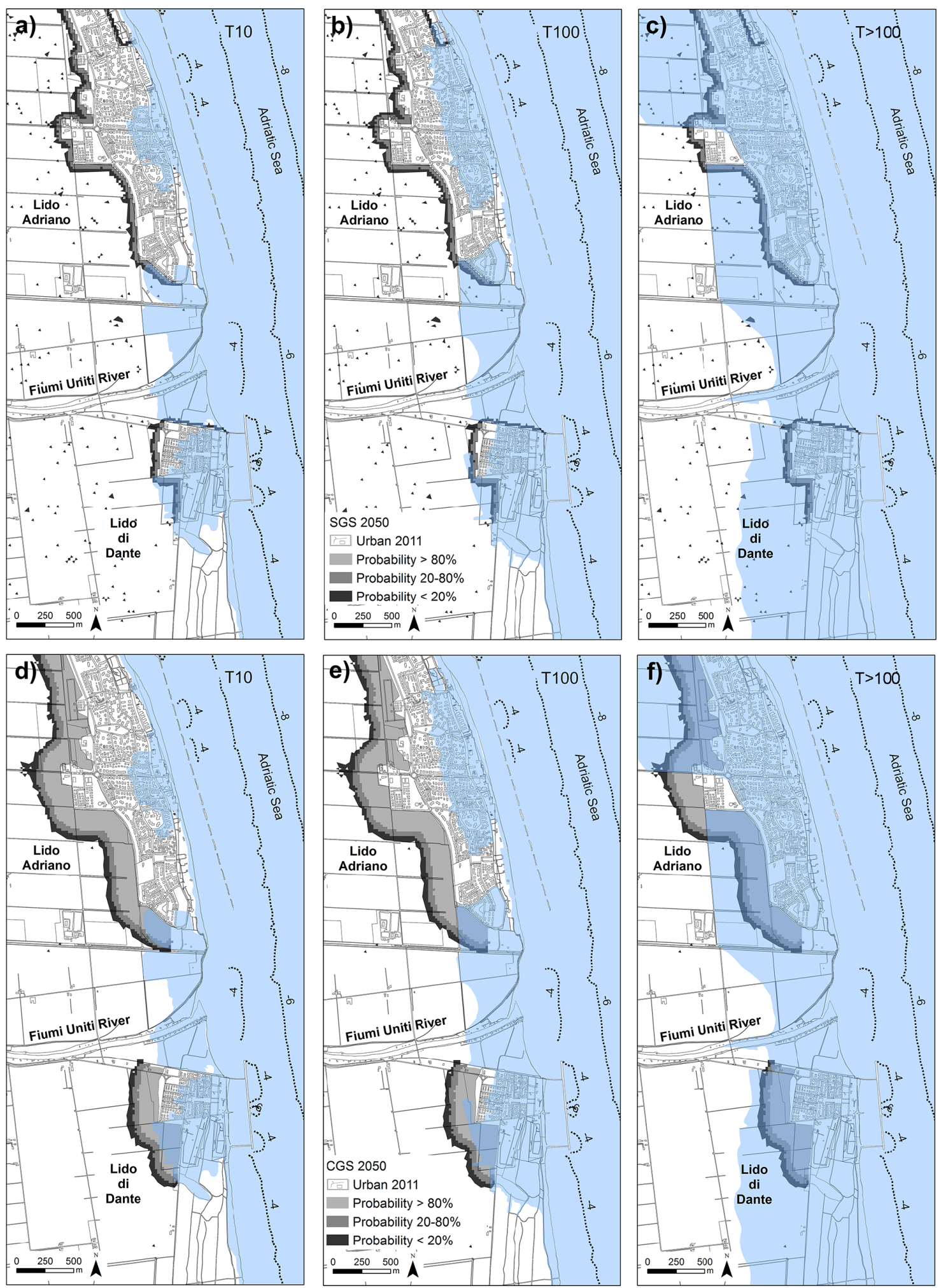

Figure 6. Overlay of coastal flood scenarios with the SGS (a-c) and the CGS (d-f) up to 2050: example of Lido Adriano-Lido di Dante, Ravenna. 


\section{Conclusions}

Among many other concerns, ongoing coastal urbanization will increase the exposure of urban settlements to coastal floods, especially in low-lying areas. Although the level of impact of climate change and sea-level rise on the future flood episodes is quite uncertain, there is a possibility of exacerbation of the problem in the future. Following a precautionary principle, scientists and planners should try to better understand the future dynamics and relations between forcing (coastal floods) and receptor (urban areas). Effective management plans could reduce damage and lead to potential economic savings, involving crucial Civil Protection issues as well (i.e. loss of human lives).

This study is a contribution to a better understanding of coastal hazard and risk, by proposing an approach that combines coastal flooding scenarios with different scenarios of urban growth, obtained using the SLEUTH model. Both methodologies demonstrate advantages in spatial analysis. The SLEUTH model outlines the benefits of applying CAbased models: the ability to capture complex system properties, self-organization of urban clusters emerging from the local interaction between cells and their neighbours and nonlinear behaviour in growth patterns. Apart from these "standard" benefits, SLEUTH offers robust historic calibration combined with Monte Carlo averaging. This provides an insight into the historic urban growth of the Emilia-Romagna coastal area. Furthermore, the code is relatively easy to manipulate. The output GIF maps were easily quantifiable, effective when visualizing urban growth scenarios and suitable for further GIS analysis.

The Cost-Distance tool has proven to be a fast and simple method for estimating future flood hazards. It is also quite replicable and exportable if the information needed as input is available (e.g. detailed DTM, forcing parameters).

Once used jointly, these two methodologies can be particularly useful in revealing flood-prone coastal areas that have a high potential for future urbanization. In other words, although exact numbers behind future urban cover projections and flood extent can be debatable, the areas where the damage is expected to be higher can be helpful to decision makers involved in land use planning.

We believe that planners and decision makers should be strongly encouraged to take probabilistic models and scenarios into account - not only ones that consider the dynamics of climate forcing but also spatial dynamic models that project urban growth. Although projecting the future is often quite uncertain, and scenarios are just a simplification of reality, these "what-if" approximations are useful to understand different directions of future development. It is clear that models have their limitations; however, rapid development of remote sensing and geographic information systems helps to supply high-quality data as input for models that can obtain more reliable results. The improvement in computer processing capabilities also reduces the time and complexity of the analysis, so specialized technical knowledge is not always essential for the use of these approaches, and the door is open to researchers, managers and planners. Finally, the visualization property of this approach can have a powerful impact, both in supporting decision-making processes and in raising awareness among the general public of the location of areas that are more vulnerable to coastal hazards.

Acknowledgements. Ivan Sekovski would like to thank his supervisors, Giovanni Gabbianelli from the Environmental Sciences Department of the University of Bologna, and Laura Del Rio from the Department of Earth Sciences, University of Cadiz, for their help and guidance. The authors would like to extend their gratitude to Paolo Ciavola of the University of Ferrara and Giovanni Salerno, consultant of the Geological Service of the Emilia-Romagna region, for their valuable support. We would also like to thank Claudia Ceppi from the Technical University of Bari for all advice regarding the SLEUTH model. Ivan Sekovski was financially supported by the Erasmus Mundus foundation (specific grant agreement number 2011-1614/001-001 EMJD).

Edited by: J. Brown

Reviewed by: three anonymous referees

\section{References}

Akın, A., Clarke, K. C., and Berberoglu, S.: The impact of historical exclusion on the calibration of the SLEUTH urban growth model, Int. J. Appl. Earth Obs., 27, 156-168, 2014.

Al-shalabi, M., Billa, L., Pradhan, B., Mansor, S., and Al-Sharif, A. A.: Modelling urban growth evolution and land-use changes using GIS based cellular automata and SLEUTH models: the case of Sana'a metropolitan city, Yemen, Environ. Earth Sci., 70, 425437, 2013.

Antrop, M.: Landscape change and the urbanization process in $\mathrm{Eu}-$ rope, Landscape Urban Plan., 67, 9-26, 2004.

Armaroli, C., Ciavola, P., Masina, M., and Perini, L.: Run-up computation behind emerged breakwaters for marine storm risk assessment, J. Coastal Res., 56, 1612-1616, 2009.

Armaroli, C., Ciavola, P., Perini, L., Calabrese, L., Lorito, S., Valentini, A., and Masina, M.: Critical storm thresholds for significant morphological changes and damage along the Emilia-Romagna coastline, Italy, Geomorphology, 143-144, 34-51, 2012.

Armaroli, C., Perini, L., Calabrese, L., Ciavola, P., and Salerno, G.: Evaluation of coastal vulnerability: comparison of two different methodologies adopted by the Emilia-Romagna Region (Italy), Geophysical Research Abstracts, vol. 16, EGU General Assembly EGU2014-11299, Vienna, Austria, 2014.

Batty, M. and Xie, Y.: Possible urban automata, Environ. Plann. B, 24, 175-192, 1997.

Bernd, M. and Nielsen, P.S.: Analysing transport costs of Danish forest wood chip resources by means of continuous cost surfaces, Biomass Bioenerg, 31, 291-298, 2007.

Caglioni, M., Pelizzoni, M., and Rabino, G. A.: Urban Sprawl: A Case Study for Project Gigalopolis Using SLEUTH Model, in: Cellular Automata, Lecture Notes in Computer Science, edited 
by: El Yacoubi, S., Chapard, B., and Bandini, S., no. 4173, 436445, Springer, New York, 2006.

Candau, J. T.: Temporal calibration sensitivity of the SLEUTH Urban Growth Model, MS thesis, Department of Geography, University of California, Santa Barbara, 2002.

Cencini, C.: Physical processes and human activities in the evolution of the Po Delta, Italy, J. Coastal Res., 14, 774-793, 1998.

Chaudhuri, G. and Clarke, K. C.: Temporal accuracy in urban growth forecasting: a study using the SLEUTH model, Trans. GIS, 18, 302-320, 2014.

Ciavola, P., Armaroli, C., Chiggiato, J., Valentini, A., Deserti, M., Perini, L., and Luciani, P.: Impact of storms along the coastline of Emilia-Romagna: the morphological signature on the Ravenna coastline (Italy), J. Coastal Res., 50, 540-544, 2007.

Clarke, K. C.: Why simulate cities?, GeoJournal, 79, 129-136, 2014.

Clarke, K. C. and Gaydos, L. J.: Loose-coupling a cellular automaton model and GIS: long-term urban growth prediction for San Francisco and Washington/Baltimore, Int. J. Geogr. Inf. Sci., 12, 699-714, 1998.

Couclelis, H.: From cellular automata to urban models: new principles for model development and implementation, Environ. Plann. B, 24, 165-174, 1997.

Davies, G. and Duncan, W.: A Least-Cost Approach to Personal Exposure Reduction, Transactions in GIS, 13, 229-246, 2009.

Decouttere, C., De Backer, K, Monbaliu, J., and Berlamont, J.: Storm wave simulation in the Adriatic Sea, in: CENAS - Coastline Evolution of the Upper Adriatic Sea due to Sea Level Rise and Natural and Anthropogenic Land Subsidence, 28, edited by: Gambolati, G., Kluwer Academic Publishers, Dodrecht, the Netherlands, 185-205, 1998.

De Sherbinin, A., Schiller, A., and Pulsipher, A.: The vulnerability of global cities to climate hazards, Environ. Urban., 19, 39-64, 2007.

Dezhkam, S., Amiri, B. J., Darvishsefat, A. A., and Sakieh, Y.: Simulating the urban growth dimensions and scenario prediction through sleuth model: a case study of Rasht County, Guilan, Iran, GeoJournal, 78, 1-14, 2013.

Dietzel, C. and Clarke, K. C.: Spatial differences in multi-resolution urban automata modeling, Transactions in GIS, 8, 479-492, 2004.

Dietzel, C. and Clarke, K. C.: Toward optimal calibration of the SLEUTH land use change model, Transactions in GIS, 11, 2945, 2007.

Ericson, J. P., Vörösmarty, C. J., Dingman, S. L., Ward, L. G., and Meybeck, M.: Effective sea-level rise and deltas: Causes of change and human dimension implications, Global Planet. Change, 50, 63-82, 2006.

European Parliament and Council of the European Communities: Directive on the assessment and management of flood risks (2007/60/EC), Official J L288/27-34, Strasbourg, 23 October 2007, 2007.

Garcia, E. S. and Loáiciga, H. A.: Sea-level rise and flooding in coastal riverine flood plains, Hydrolog. Sci. J., 59, 204-220, 2014.

Gazulis, N. and Clarke, K. C.: Exploring the DNA of Our Regions: Classification of Outputs from the SLEUTH Model, in: Cellular Automata. Lecture Notes in Computer Science, edited by: El
Yacoubi, S., Chapard, B., and Bandini, S., no. 4173, 462-471, Springer, New York, 2006.

Goldstein, N. C.: Brains vs. brawn - comparative strategies for the calibration of a cellula automata-based urban growth model, in: Geo Dynamics, edited by: Atkinson, P., Foody, G., Darby, S., and Wu, F., CRC Press, Boca Raton, 249-272, 2004.

Hanson, S., Nicholls, R., Ranger, N., Hallegatte, S., Corfee-Morlot, J., Herweijer, C., and Chateau, J.: A global ranking of port cities with high exposure to climate extremes, Climatic Change, 104, 89-111, 2011.

Harley, M. D. and Ciavola, P.: Managing local coastal inundation risk using real-time forecasts and artificial dune placements, Coast. Eng., 77, 77-90, 2013.

Herold, M., Goldstein, N. C., and Clarke, K. C.: The spatiotemporal form of urban growth: measurement, analysis and modeling, Remote Sens. Environ., 86, 286-302, 2003.

Idroser: Piano progettuale per la difesa della costa EmilianoRomagnola - aspetti meteomarini e determinazione del trasporto litoraneo, vol. III, Regione Emilia-Romagna, Bologna, Italy, 1982.

Idroser: Progetto di Piano per la difesa del mare e la riqualificazione ambientale del litorale della Regione Emilia-Romagna, Regione Emilia-Romagna, Bologna, Italy, 1996.

IOC/UNESCO, IMO, FAO and UNDP: A Blueprint for Ocean and Coastal Sustainability, IOC/UNESCO, Paris, 2011.

Irwin, E. G. and Geoghegan, J.: Theory, data , methods: developing spatially explicit economic models of land use change, Agr. Ecosyst. Environ., 85, 7-23, 2001.

Jantz, C. A. and Goetz, S. J.: Analysis of scale dependencies in an urban land-use-change model, Int. J. Geogr. Inf. Sci., 19, $217-$ 241, 2005.

Jantz, C. A., Goetz, S. J., and Shelley, M. K.: Using the SLEUTH urban growth model to simulate the impacts of future policy scenarios on urban land use in the Baltimore-Washington metropolitan area, Environ. Plann. B, 30, 251-271, 2003.

Jantz, C. A., Goetz, S. J., Donato, D., and Claggett, P.: Designing and implementing a regional urban modeling system using the SLEUTH cellular urban model, Comput. Environ. Urban, 34, 1$16,2010$.

Jongman, B., Ward, P. J., and Aerts, J. C. J. H.: Global exposure to river and coastal flooding: Long term trends and changes, Global Environ Chang., 22, 823-835, 2012.

Kreibich, H., van den Bergh, J. C. J. M. , Bouwer, L. M., Bubeck, P., Ciavola, P., Green, C., Hallegatte, S., Logar, I., Meyer, V., Schwarze, R., and Thieken, A. H.: Costing natural hazards, Nature Climate Change, 4, 303-306, 2014.

Leao, S., Bishop, I., and Evans, D.: Simulating Urban Growth in a Developing Nation's Region Using a Cellular Automata-Based Model, J. Urban Plan. Dev. Div., 130, 145-158, 2004.

Lequeux, Q. and Ciavola, P.: Methods for Estimating the Costs of Coastal Hazards, Final report WP7, CONHAZ Project,http: //conhaz.org/CONHAZ\%20REPORT\%20WP07_1_FINAL.pdf, (last access: 27 March 2015), 2011.

Li, X. and Yeh, A. G.: Modelling sustainable urban development by the integration of constrained cellular automata and GIS, Int. J. Geogr. Inf. Sci., 14, 131-152, 2000.

Masina, M. and Ciavola, P.: Analisi dei livelli marini estremi e delle acque alte lungo il litorale ravennate, Studi Costieri, 18, 87-101, 2011. 
McGranahan, G., Balk, D., and Anderson, B.: The rising tide: assessing the risks of climate change and human settlements in low elevation coastal zones, Environ. Urban., 19, 17-37, 2007.

Meyer, V., Becker, N., Markantonis, V., Schwarze, R., van den Bergh, J. C. J. M., Bouwer, L. M., Bubeck, P., Ciavola, P., Genovese, E., Green, C., Hallegatte, S., Kreibich, H., Lequeux, Q., Logar, I., Papyrakis, E., Pfurtscheller, C., Poussin, J., Przyluski, V., Thieken, A. H., and Viavattene, C.: Review article: Assessing the costs of natural hazards - state of the art and knowledge gaps, Nat. Hazards Earth Syst. Sci., 13, 1351-1373, doi:10.5194/nhess-13-1351-2013, 2013.

Neumann, B., Vafeidis, A. T., Zimmermann, J., and Nicholls, R. J.: Future coastal population growth and exposure to sea-level rise and coastal flooding - A global assessment, PLoS ONE, 10, e0118571, doi:10.1371/journal.pone.0118571, 2015.

Oguz, H., Klein, A. G., and Srinivasan, R.: Using the Sleuth Urban Growth Model to Simulate the Impacts of Future Policy Scenarios on Urban Land Use in the Houston-Galveston-Brazoria, CMSA, Research Journal of Social Sciences, 2, 72-82, 2007.

Onsted, J. and Clarke, K. C.: The inclusion of differentially assessed lands in urban growth model calibration: a comparison of two approaches using SLEUTH, Int. J. Geogr. Inf. Sci., 26, 881-898, 2012.

O'Sullivan, D. and Torrens, P. M.: Cellular Models of Urban Systems, in: Theoretical and Practical Issues on Cellular Automata, edited by: Bandini, T., and Worsch, S., Proceedings of the Fourth International Conference on Cellular Automata for Research and Industry (ACRI 2000), 108-116, Karlsruhe, Germany, SpringerVerlag, London, 2000.

Perini, L., Calabrese, L., Deserti, L. M., Valentini, A., Ciavola, P., and Armaroli, C.: Le Mareggiate e gli Impatti Sulla Costa in Emilia-Romagna 1946-2010, Bologna: I Quaderni di ARPA - Regione Emilia Romagna, ARPA Emilia-Romagna, Bologna, Italy, 2011.

Perini, L., Calabrese, L., Salerno, G., and Luciani, P.: Seaflood hazard mapping in Emilia-Romagna, in: 7th EureGeo Conference - EUropean Congress on REgional GEOscientific Cartography and Information Systems, Regione EmiliaRomagna, Bologna, 12-15 June 2012, vol. 1, 334-335, available at: http://mappegis.regione.emilia-romagna.it/gstatico/ documenti/euregeo/7th_EUREGEO_Volume_1.pdf (last access: 27 March 2015), 2012.

Perini, L., Calabrese, L., Salerno, G., Ciavola, P., and Armaroli, C.: Evaluation of coastal vulnerability to flooding: comparison of two different methodologies adopted by the Emilia-Romagna Region (Italy), Nat. Hazards Earth Syst. Sci. Discuss., 3, 43154352, doi:10.5194/nhessd-3-4315-2015, 2015.

Poulter, B. and Halpin, P. N.: Raster modelling of coastal flooding from sea-level rise, Int. J. Geog. Inf. Sci., 22, 167-182, 2008.

Preciso, E., Salemi, E., and Billi, P.: Land use changes, torrent control works and sediment mining: effects on channel morphology and sediment flux, case study of the Reno River (Northern Italy), Hydrol. Process., 26, 1134-1148, 2012.

Rafiee, R., Mahiny, A. S., Khorasani, N., Darvishsefat, A. A., and Danekar, A.: Simulating urban growth in Mashad City, Iran through the SLEUTH model (UGM), Cities, 26, 19-26, 2009.

Regione Emilia-Romagna: Servizio Geologico Sismico e dei Suoli 2010, Il Sistema Mare-Costa dell'Emilia-Romagna, edited by:
Perini, L. and Calabrese, L., Regione Emilia-Romagna, Bologna, Italy, 2010a.

Regione Emilia-Romagna: Factbook, Quaderni di Statistica/a cura del Servizio Controllo Strategico e Statistica della Regione Emilia-Romagna, Centro Stampa Regione Emilia-Romagna, Bologna, 2010b.

Regione Emilia-Romagna: Mappe della pericolosità e del rischio di alluvione, Distretto Padano, Ambito Marino-Costiero, Regione Emilia-Romagna Servizio Geologico, Sismico e dei Suoli, avialable at: http://ambiente.regione.emilia-romagna.it/suolo-bacino/ sezioni/piano-di-gestione-del-rischio-alluvioni (last access: 27 March 2015), 27 pp., 2012a (in Italian).

Regione Emilia-Romagna: Mappe della pericolosità e del rischio di alluvione, Distretto Appennino Settentrionale, Ambito Marino-Costiero, Regione Emilia-Romagna, Servizio Geologico, Sismico e dei Suoli, available at: http://ambiente.regione.emilia-romagna.it/suolo-bacino/sezioni/ piano-di-gestione-del-rischio-alluvioniTS12, 28 pp., 2012b (in Italian).

Regione Emilia-Romagna: Valutazione globale provvisoria dei problemi relativi alla valutazione e gestione del rischio di alluvione nella parte a_erente alla Regione Emilia Romagna del Distretto Idrografico dell'Appennino Settentrionale, mappe della pericolosità e del rischio, Piano di Gestione del Rischio di Alluvioni (art. 6 Direttiva 2007/60/CE e art. 6 D.Lgs 49/2010), Relazione Tecnica sugli Aspetti Metodologici, Regione Emilia Romagna, available at: http://ambiente.regione.emilia-romagna.it/suolo-bacino/ sezioni/piano-di-gestione-del-rischio-alluvioni (last access: 27 March 2015), 108 pp., 2013 (in Italian).

Regione Emilia-Romagna: Valutazione globale provvisoria dei problemi relativi alla valutazione e gestione del rischio di alluvione nella parte afferente alla Regione Emilia - Romagna del Distretto Idrografico dell'Appennino Settentrionale, documento per la consultazione pubblica, Regione EmiliaRomagna, available at: http://ambiente.regione.emilia-romagna. it/suolo-bacino/sezioni/piano-di-gestione-del-rischio-alluvioni/ piano-gestione-del-rischio-alluvioni/documenti-1/ valutazione-globale-provvisoria/at_download/file/Valutazione\% 20Globale\%20Provvisoria_REV3_RER.pdf (last access: 27 March 2015), 38 pp., 2013 b (in Italian).

Rounsevell, M. D. A., Reginster, I., Araujo, M. B., Carter, T. R., Dendoncker, N., Ewert, F., House, J. I., Kankaanpaa, S., Leemans, R., Metzger, M. J., Schmit, C., Smith, P., and Tuck, G.: A coherent set of future land use change scenarios for Europe, Agr. Ecosyst. Environ., 114, 57-68, 2006.

Sekovski, I., Stecchi, F., Mancini, F., and Del Rio, L.: Image classification methods applied to shoreline extraction on very highresolution multispectral imagery, Int. J. Remote Sens., 35, 35563578, 2014.

Silva, E. A. and Clarke, K. C.: Calibration of the SLEUTH urban growth model for Lisbon and Porto, Portugal, Comput. Environ. Urban, 26, 525-552, 2002.

Sims, S. A., Seavey, J. R., and Curtin, C. G.: Room to move? Threatened shorebird habitat in the path of sea level rise - dynamic beaches, multiple users, and mixed ownership: a case study from Rhode Island, USA, J. Coast. Conservat., 17, 339-350, 2013. 
Solecki, W. D. and Oliveri, C.: Downscaling climate change scenarios in an urban land use change model, J. Environ. Manage., 72, 105-115, 2004.

Stevens, A. J., Clarke, D., Nicholls, R. J., and Wadey, M. P.: Estimating the long-term historic evolution of exposure to flooding of coastal populations, Nat. Hazards Earth Syst. Sci. Discuss., 3, 1681-1715, doi:10.5194/nhessd-3-1681-2015, 2015.

Syphard, A. D., Clarke, Keith C., and Franklin, J.: Using a cellular automaton model to forecast the effects of urban growth on habitat pattern in southern California, Ecol. Complex., 2, 185-203, 2005.

Syphard, A. D., Clarke, K. C, Franklin, J., Regan, H. M., and Mcginnis, M.: Forecasts of habitat loss and fragmentation due to urban growth are sensitive to source of input data, J. Environ. Manage., 92, 1882-1893, 2011.

Taramelli, A., Di Matteo, L., Ciavola, P., Guadagnano, F., and Tolomei, C.: Temporal evolution of patterns and processes related to subsidence of the coastal area surrounding the Bevano River mouth (Northern Adriatic) - Italy, Ocean Coast. Manage., 108, 74-88, doi:10.1016/j.ocecoaman.2014.06.021, 2015.

Teatini, P., Ferronato, M., Gambolati, G., Bertoni, W., and Gonella, M.: A century of land subsidence in Ravenna, Italy, Environ. Geol., 47, 831-846, 2005.
Torrens, P. M.: Automata-based models of urban systems, in: Advanced Spatial Analysis, edited by: Longley, P. and Batty, M., The CASA Book of GIS, ESRI Press, Redlands CA, 61-79, 2003.

UNFPA (United Nations Populations Fund): State of the World Population; Unleashing the Potential of Urban Growth, UNFPA, New York, 2007.

United Nations: World Urbanization Prospects: The 2014 Revision, Highlights (ST/ESA/SER.A/352), Department of Economic and Social Affairs, Population Division, New York, 2014.

White, R. and Engelen, G.: High-resolution integrated modelling of the spatial dynamics of urban and regional systems, Comp. Environ. Urban, 24, 383-400, 2000.

Wu, X., Hu, Y., He, H. S., Bu, R., Onsted, J., and Xi, F.: Performance Evaluation of the SLEUTH Model in the Shenyang Metropolitan Area of Northeastern China, Environ. Model. Assess., 14, 221-230, 2009.

Xingong, L., Grady, C. J., and Townsend Peterson, A.: Delineating Sea Level Rise Inundation Using a Graph Traversal Algorithm, Mar. Geod., 37, 267-281, 2014.

Yang, X. and Lo, C. P.: Modelling urban growth and landscape changes in the Atlanta metropolitan area, Int. J. Geogr. Inf. Sci., 17, 463-488, 2003. 